\title{
Bibliography of Professor G. H. Bolt
}

Vries, D. A. de \& G. H. Bolt, 1949. Enige beschouwingen omtrent het gedrag van de tensimeter. Mededelingen Landbouwhogeschool Wageningen 49: 245-254.

Schuffelen, A. C. \& G. H. Bolt, 1950 . Some notes on the synthesis of humus compounds. Landbouwkundig Tijdschrift 62: 333-338.

Bolt, G. H., 1952. The significance of the measurements of the zeta potential and the membrane potential in soil and clay water systems. M.Sc. Thesis, Cornell University, $73 \mathrm{pp}$.

Bolt, G. H. \& M. Peech, 1953. The application of the Gouy theory to soil water systems. Soil Science Society of America Proceedings 17: 210-213.

Peech, M., R. A. Olsen \& G. H. Bolt, 1953. The significance of potentiometric measurements involving liquid junction in clay and soil suspension. Soil Science Society of America Proceedings 17: 214-218.

Bolt, G. H., 1954. Physico-chemical properties of the electric double layer on planar surfaces. Ph.D.Thesis, Cornell University, $104 \mathrm{pp}$.

Gill, W. R. \& G. H. Bolt, 1955. Pfeffer's studies of the root growth pressures exerted by plants. Agronomy Journal 47: 166-168.

Bolt, G. H., 1955. Analysis of the validity of the Gouy-Chapman theory of the electric double layer. Journal of Colloid Science 10: 206-218.

Bolt, G. H., 1955. Ion adsorption by clays. Soil Science 79: 267-276.

Bolt, G. H. \& R. D. Miller, 1955. Comparison studies of illite suspensions. Soil Science Society of America Proceedings 19: 285-288.

Bolt, G. H., 1956. Physico-chemical analysis of the compressibility of pure clays. Geotechnique 6: 86-93.

Bolt, G. H. \& B. P. Warkentin, 1956. Influence of the method of sample preparation on the negative adsorption of anions in montmorillonite suspensions. Proceedings 6th International Congress of Soil Science (Paris), Vol. B, p. 33-40.

Bolt, G. H., 1957. Determination of the charge density of silica soils. Journal of Physical Chemistry 61: 1166-1169.

Warkentin, B. P., R. D. Miller \& G. H. Bolt, 1957. Swelling pressure of montmorillonite. Soil Science Society of America Proceedings 21: 495-497.

Bolt, G. H., 1957. Adsorptie-evenwichten in de bodem. Openbare les, Landbouwhogeschool, Wageningen, $20 \mathrm{pp}$.

Bolt, G. H. \& B. P. Warkentin, 1958. The negative adsorption of anions in clay suspensions. Kolloid Zeitschrift 156: 41-46.

Bolt, G. H., 1958. De bepaling van het vochtgehalte en het volumegewicht van de bodem met behulp van neutronen en $\gamma$-stralen. Landbouwkundig Tijdschrift 70 : 282-286.

Bolt, G. H., A. R. P. Janse \& A. C. Schuffelen, 1958. Definition and determination of soil structure. International Symposium on Soil Structure, Gent. Mededelingen Landbouwhogeschool en Opzoekingsstations van de Staat te Gent 24: 251256. 
Schuffelen, A. C. \& G. H. Bolt, 1958. Ionic equilibrium in soils. Band II. Vortragsveröffentlichungen der zweiten und vierten Kommission der IBG, Hamburg, p. 131-146.

Bolt, G. H. \& R. D. Miller, 1958. Calculation of total and component potentials of water in soil. Transactions American Geophysical Union 39: 917-928.

Lagerwerff, J. V. \& G. H. Bolt, 1959. Theoretical and experimental analysis of Gapon's equation for ion exchange. Soil Science 87: 217-222.

Bolt, G. H. \& M. J. Frissel, 1960. Thermodynamics of soil moisture. Netherlands Journal of Agricultural Science 8: 57-78.

Janse, A. R. P. \& G. H. Bolt, 1960. The determination of the air permeability of soils. Netherlands Journal of Agricultural Science 8: 124-131.

Bolt, G. H. \& M. J. Frissel, 1960. The preparation of clay suspensions with specified ionic composition by means of exchange resins. Soil Science Society of America Proceedings 24: 172-177.

Bolt, G. H., 1960. Cations in relation to clay surfaces. Proceedings 7 th International Congress of Soil Science (Madison), Vol. 2, p. 321-352.

Bolt, G. H., 1961. The pressure filtrate of colloidal suspensions. I. Theoretical considerations. Kolloid Zeitschrift 175: 33-39.

Bolt, G. H., 1961. The pressure filtrate of colloidal suspensions. II. Experimental data on homoionic clays. Kolloid Zeitschrift 175: 144-150.

Alexander, G. P. \& G. H. Bolt, 1961. Aquasols of positively-charged coated silica particles and their production. U.S. Patent $3,007,878$.

Bolt, G. H., 1962. Fysisch-chemische aspecten van het vochttransport in poreuze media. De Ingenieur 28: 1-6.

Frissel, M. J. \& G. H. Bolt, 1962. Interaction between certain ionizable organic compounds (herbicides) and clay minerals. Soil Science 94: 284-291.

Sumner, M. E. \& G. H. Bolt, 1962. Isotopic exchange of potassium in an illite under equilibrium conditions. Soil Science Society of America Proceedings 26: 541544.

Bolt, G. H., 1962. Transportverschijnselen in de bodem. Landbouwkundig Tijdschrift 74: 926-933.

Bolt, G. H., 1963. Differentiatie en specialisatie in de algemene bodemkunde. Inaugurele rede, Landbouwhogeschool, Wageningen, $17 \mathrm{pp}$.

Bolt, G. H., M. E. Sumner \& A. Kamphorst, 1963. A study of the equilibria between three categories of potassium in an illitic soil. Soil Science Society of America Proceedings 27: 294-299.

Bolt, G. H. \& F. A. M. de Haan, 1963. Determination of ion exchange characteristics of soils and clays. Report Research Contract, IAEA, $34 \mathrm{pp.}$

Lahav, N. \& G. H. Bolt, 1963. Interaction between calcium carbonates and bentonite suspensions. Nature 200: 1343-1344.

Haan, F. A. M. de \& G. H. Bolt, 1963. Determination of anion adsorption by clays. Soil Science Society of America Proceedings 27: 636-640.

Bolt, G. H. \& B. G. M. Pieters, 1964. Assessing the activity concentration of $\beta$ emitters by means of the end-window G.M. tube. Analytica Chimica Acta 31: 6470 . 
Haan, F. A. M. de, G. H. Bolt \& B. G. M. Pieters, 1964. Application of radioactive $\mathrm{K}$-isotopes to the determination of $\mathrm{K}$-adsorption and $\mathrm{K}$-release characteristics of potassium-containing materials. International Journal of Applied Radiation and Isotopes 15: 221-229.

Lahav, N. \& G. H. Bolt, 1964. Self-diffusion of $\mathrm{Ca}^{45}$ into certain carbonates. Soil Science 97: 293-299.

Bolt, G. H. \& F. A. M. de Haan, 1964. Diffusion of alkali chlorides in clay-water systems: A discussion of a report by Gordon R. Dutt and Philip F. Low. I. Comment on the Dutt-Low report. Soil Science 97: 344-346.

Reiniger, P., N. Lahav \& G. H. Bolt, 1964. Determination of the cation exchange characteristics of calcareous soils. Proceedings 8th International Congress of Soil Science (Bucharest), Vol. III, p. 479-488.

Schuffelen, A. C., F. F. R. Koenigs \& G. H. Bolt, 1964. The isolation of the soil solution with the aid of filter paper tablets. Proceedings 8 th International Congress of Soil Science (Bucharest), Vol. III, p. 519-528.

Bolt, G. H. \& J. V. Lagerwerff, 1965. Consequences of electrolyte redistribution during pressure-membrane equilibration of clays. Soil Science 99: 147-153.

Bolt, G. H. \& A. L. Page, 1965. Ion-exchange equations based on double-layer theory. Soil Science 99: 357-361.

Haan, F. A. M. de, G. H. Bolt \& B. G. M. Pieters, 1965. Diffusion of potassium-40 into an illite during prolonged shaking. Soil Science Society of America Proceedings 29: 528-530.

Bolt, G. H. \& F. A. M. de Haan, 1965. Interactions between anions and soil constituents. IAEA Technical Reports Series 48: 94-110.

Bolt, G. H., 1966. Soil physical processes as boundary conditions to ion uptake. IAEA Technical Reports Series 65: 57-65.

Day, P. R., G. H. Bolt \& D. M. Anderson, 1967. Nature of soil water. In: Agronomy Monograph 11, p. 193-208. American Society of Agronomy, Madison, WI, USA.

Bolt, G. H., 1967. Cation-exchange equations used in soil science - A review. Netherlands Journal of Agricultural Science 15: 81-103.

Bolt, G. H. \& P. H. Groenevelt, 1967. Thermostatics and thermodynamics of soil water. Proceedings International Soil Water Symposium, ICID, Praha, 17 pp.

Shainberg, I., W. D. Kemper \& G. H. Bolt, 1967. Discussion of the paper by I. Shainberg and W. D. Kemper entitled: Ion exchange equilibria on montmorillonite. Soil Science 104: 441-453.

Laudelout, H., R. van Bladel, G. H. Bolt \& A. L. Page, 1968. Thermodynamics of heterovalent cation exchange reactions in a montmorillonite clay. Transactions Faraday Society 64: 1477-1488.

Bolt, G. H. \& C. J. G. Winkelmolen, 1968. Calculations of the standard free energy of cation exchange in clay systems. Israel Journal of Chemistry 6: 175-187.

Bolt, G. H., 1968. On the use of radioactive tracers in diffusion experiments. Soil Science Society of America Proceedings 32: 889-890.

Groenevelt, P. H. \& G. H. Bolt, 1969. Non-equilibrium thermodynamics of the soil-water system. Journal of Hydrology 7: 358-388. 
Groenevelt, P. H. \& G. H. Bolt, 1969. Permiselective properties of porous materials as calculated from diffuse double-layer theory. Proceedings IAHR Symposium on Fundamentals of Transport Phenomena in Porous Media, Haifa, p. 241255.

Bolt, G. H. \& P. H. Groenevelt, 1969. Coupling phenomena as a possible cause of 'Non-Darcian' behaviour of water in soil. Bulletin of the International Association of Scientific Hydrology 14: 17-26.

Bolt, G. H. \& F. F. R. Koenigs, 1972. Some principles with respect to the interpretation of suction profiles in the field. Transactions of Commissions V and VI of the ISSS, p. 515-519.

Bolt, G. H. \& F. F. R. Koenigs, 1972. Physical and chemical aspects of the stability of soil aggregates. International Meeting on the Fundamentals of Soil Conditioning, Gent. Mededelingen Fakulteit der Landbouwwetenschappen Gent 37: 955973.

Groenevelt, P. H. \& G. H. Bolt, 1972. Water retention in soil. Soil Science 113: 238-245.

Bolt, G. H. \& P. H. Groenevelt, 1972. Coupling between transport processes in porous media. Proceedings 2nd IAHR-ISSS Symposium on Fundamentals of Transport Phenomena in Porous Media (Guelph), p. 630-652.

Groenevelt, P. H. \& G. H. Bolt, 1972. Coupling between transport processes in an anisotropic mixture of fluids and solid particles. Proceedings 2nd IAHR-ISSS Symposium on Fundamentals of Transport Phenomena in Porous Media (Guelph), p. 653-666.

Reiniger, P. \& G. H. Bolt, 1972. Theory of chromatography and its application to cation exchange in soils. Netherlands Journal of Agricultural Science 20: 301-313.

Groenevelt, P. H. \& G. H. Bolt, 1973. Theory of transport in soils: generalized approaches based on continuum mechanics and thermodynamics of irreversible processes. In: A. Hadas, D. Swartzendruber, P. E. Rijtema, M. Fuchs \& B. Yaron (Eds.), Physical aspects of soil water and salts in ecosystems. Ecological Studies 4: p. 43-48. Springer-Verlag, Berlin.

Beek, C. G. E. M. van \& G. H. Bolt, 1973. The relationship between the composition of the exchange complex and the composition of the soil solution. In: A. Hadas, D. Swartzendruber, P. E. Rijtema, M. Fuchs \& B. Yaron (Eds.), Physical aspects of soil water and salts in ecosystems. Ecological Studies 4, p. 379-388. Springer-Verlag, Berlin.

Bolt, G. H. \& P. H. Groenevelt, 1974. Termostatyk i termodynamika wody gruntowej. Archivum Hydrotechniki 21: 371-389.

Stroosnijder, L. \& G. H. Bolt, 1974. Nomographic interpretation of water absorption data in terms of a two-parametric diffusivity water-content function. Soil Science Society of America Proceedings 38: 876-880.

Stroosnijder, L. \& G. H. Bolt, 1975. Reply to a note of J. Y. Parlange. Soil Science Society of America Proceedings 39: 1014.

Bolt, G. H., 1975. Final report of the second committee on terminology in soil physics of the International Soil Science Society. International Society of Soil Science Bulletin 48: 16-22. 
Bolt, G. H. \& M. G. M. Bruggenwert (Eds.), 1976. Soil chemistry. A. Basic elements, 1st ed. 1976, 2nd revised ed. 1978, Japanese ed. 1979, 3rd ed. 1981. Elsevier, Amsterdam.

Bolt, G. H. \& M. G. M. Bruggenwert, 1976. Composition of the soil. In: G. H. Bolt \& M. G. M. Bruggenwert (Eds.), Soil chemistry. A. Basic elements, 3rd ed., 1981, p. 1-12.

Novozamsky, I., J. Beek \& G. H. Bolt, 1976. Chemical equilibria. In: G. H. Bolt \& M. G. M. Bruggenwert (Eds.), Soil chemistry. A. Basic elements, 3rd ed., 1981, p. 13-42.

Bolt, G. H., 1976. Surface interaction between the soil solid phase and the soil solution. In: G. H. Bolt \& M. G. M. Bruggenwert (Eds.), Soil chemistry. A. Basic elements, 3rd ed., 1981, p. 43-53.

Bolt, G. H., M. G. M. Bruggenwert \& A. Kamphorst, 1976. Adsorption of cations by soil. In: G. H. Bolt \& M. G. M. Bruggenwert (Eds.), Soil chemistry. A. Basic elements, 3rd ed., 1981, p. 54-90.

Bolt, G. H., 1976. Adsorption of anions by soil. In: G. H. Bolt \& M. G. M. Bruggenwert (Eds.), Soil chemistry. A. Basic elements, 3rd ed., 1981, p. 91-95.

Bolt, G. H., 1976. Transport and accumulation of soluble soil components. In: $G$. H. Bolt \& M. G. M. Bruggenwert (Eds.), Soil chemistry. A. Basic elements, 3rd ed., 1981, p. 126-140.

Kamphorst, A. \& G. H. Bolt, 1976. Saline and sodic soils. In: G. H. Bolt \& M. G. M. Bruggenwert (Eds.), Soil chemistry. A. Basic elements, 3rd ed., 1981, p. 171-191.

Bolt, G. H. (Ed.), 1979. Soil chemistry. B. Physico-chemical models, 1st ed. 1979, 2nd revised ed. 1982. Elsevier, Amsterdam.

Bolt, G. H., 1979. The ionic distribution in the diffuse double layer. In: G. H. Bolt (Ed.), Soil chemistry. B. Physico-chemical models, 2nd ed., 1982, p. 1-26.

Bolt, G. H., 1979. Thermodynamics of cation exchange. In: G. H. Bolt (Ed.), Soil chemistry. B. Physico-chemical models, 2nd ed., 1982, p. 27-46.

Bolt, G. H., 1979. Theories of cation adsorption by soil constituents: distribution equilibrium in electrostatic fields. In: G. H. Bolt (Ed.), Soil chemistry. B. Physico-chemical models, 2nd ed., 1982, p. 47-76.

Bolt, G. H. \& F. A. M. de Haan, 1979. Anion exclusion in soil. In: G. H. Bolt (Ed.), Soil chemistry. B. Physico-chemical models, 2nd ed., 1982, p. 233-257.

Bolt, G. H., 1979. Movement of solutes in soil: principles of adsorption/exchange chromatography. In: G. H. Bolt (Ed.), Soil chemistry. B. Physico-chemical models, 2nd ed., 1982, p. 285-348.

Bolt, G. H., 1979. Electrochemical phenomena in soil and clay systems. In: G. H. Bolt (Ed.), Soil chemistry. B. Physico-chemical models, 2nd ed., 1982, p. 387432.

Bolt, G. H. \& W. H. van Riemsdijk, 1982. Ion adsorption on inorganic variable charge constituents. In: G. H. Bolt (Ed.), Soil chemistry. B. Physico-chemical models, 2nd ed., p. 459-504.

Haan, F. A. M. de \& G. H. Bolt, 1979. Pollution. In: R. W. Fairbridge \& C. W. Finkl (Eds.), The encyclopedia of soil science, Part I, p. 386-389. Hutchinson 
and Ross, Stroudsburg, PA, USA.

Bolt, G. H. \& M. G. M. Bruggenwert, 1981. On the interaction between solid and liquid phase in soil, emphasizing the use of models. International Society of Soil Science Bulletin 60: 85-88.

Bolt, G. H., 1981. The nature properties of soil colloid surfaces. International Society of Soil Science Bulletin 60: 120-124.

Harmsen, K. \& G. H. Bolt, 1982. Movement of ions in soil. I. Ion exchange and precipitation. Geoderma 28: 85-101.

Harmsen, K. \& G. H. Bolt, 1982. Movement of ions in soil. II. Ion exchange and dissolution. Geoderma 28: 103-116.

Bolt, G. H., 1985. Transport of solutes through soil. Zeszyty Problemowe Postepow Nauk Rolniczych 220: 417-422.

Bolt, G. H., 1983. Transport phenomena in charged porous media. Zeszyty Problemowe Postepow Nauk Rolniczych 220: 423-426.

Stroosnijder, L. \& G. H. Bolt, 1984. The moisture characteristic of heavy clay soils. Proceedings ISSS Symposium on Water and Solute Transport in Heavy Clay Soils (Wageningen), p. 324-329.

Bolt, G. H. \& H. van Olphen, 1985. Book review of G. Sposito: Surface Chemistry of Soils. Clays and Clay Minerals 33: 367.

Bolt, G. H., 1985. Transport of solutes in soil: basic features of front retardation. Water Science and Technology 17: 87-99.

Riemsdijk, W. H. van, G. H. Bolt, L. K. Koopal \& J. Blaakmeer, 1986. Electrolyte adsorption on heterogeneous surfaces: adsorption models. Journal of Colloid and Interface Science 109: 219-228.

Riemsdijk, W. H. van, G. H. Bolt \& L. K. Koopal, 1986. Surface heterogeneity and electrolyte adsorption. Proceedings of the 2nd ISSS-NATO Workshop on Soil Colloid Surfaces, Ghent (in press).

Bolt, G. H. \& W. H. van Riemsdijk, 1987. Surface chemical processes in soil. In: W. Stumm (Ed.), Aquatic surface chemistry, p. 127-164. Wiley Interscience, New York.

Riemsdijk, W. H. van, J. C. M. de Wit, L. K. Koopal \& G. H. Bolt, 1987. Metal ion adsorption on heterogeneous surfaces: Adsorption models. Journal of Colloid and Interface Science 116: 511-522.

Bolt, G. H., 1987. Cation adsorption in aqueous clay systems: An introductory review. In: L. G. Schultz, H. van Olphen \& F. A. Mumpton (Eds.), Proceedings International Clay Conference (Denver, 1985), p. 301·304.

Bruggenwert, M. G. M., G. H. Bolt \& T. Hiemstra, 1987. Acid-base systems in soil. Transactions 13th Congress of the International Society of Soil Science (Hamburg, 1986), Vol. V, p.51-58.

Berge, H. F. M. ten \& G. H. Bolt, 1987. Coupling between liquid flow and heat flow in porous media: a connection between two classical approaches. Transport in Porous Media 2 (in press). 